\title{
Manufacturing Matters: A Case Study of Alabama
}

\author{
Nicholas Bolden $^{1 *} \quad$ Cal Clark $^{2} \quad$ James Agbodzakey $^{3}$ \\ 1.Department of Politics, Philosophy, and Public Administration, Columbus State University, Columbus, GA, \\ U.S.A. \\ 2.Department of Political Science, Auburn University, Auburn, AL, U.S.A. \\ 3.SERCH/Public Leadership, University of North Texas at Dallas, Dallas, TX, U.S.A \\ * E-mail of the corresponding author: bolden_nicholas@columbusstate.edu
}

\begin{abstract}
Over the last fifty years, the United States has been marked by two important secular trends. One is a continuous increase in income inequality. Second, the nation has transitioned through three periods of manufacturing: (a) "The Industrial Period" during 1945-1979, (b) the "Deindustrialization of America" during 1980-2000, and (c) the "Reindustrialization of America" during 2000-present, as it began to shift to an economy largely dominated by service and knowledge jobs, with a major reduction in labor-intensive manufacturing. This study examines the relationship between manufacturing employment and income inequality in the state of Alabama to test the hypothesis that manufacturing plays a key role in moderating inequality. In particular, we consider whether manufacturing or other economic and demographic factors are determinants of the rising income inequality in Alabama. We control for other factors that are also likely to be related to rising income inequality. We employ empirical techniques that are best suited to address potential econometric problems in the empirical work. In general, our results indicate that manufacturing does indeed play a key role in moderating inequality. Other key findings are that more educated communities have less inequality, that rural areas have especially high inequality, that counties with a high proportion of African Americans face disproportionately high inequality, and that the poorest counties have the highest level of inequality
\end{abstract}

Keywords: Manufacturing, Deindustrialization, Reindustrialization, Income Inequality

DOI: $10.7176 / \mathrm{JESD} / 11-6-12$

Publication date:March $31^{\text {st }} 2020$

\section{Introduction}

Over the last fifty years, the United States has been marked by two important secular trends. One is a continuous increase in income inequality (Bartels, 2008; Dadush, Dervis, Milsom, \& Stancil, 2012; Danziger \& Gottschalk, 1995). Second, the nation has transitioned through three periods of manufacturing: (a) "The Industrial Period" during 1945-1979, (b) the "Deindustrialization of America" during 1980-2000, and (c) the "Re-industrialization of America" during 2000-present, as it began to shift to an economy largely dominated by service and knowledge jobs, with a major reduction in labor-intensive manufacturing (Bluestone \& Harrison, 1982; Gordon, 2016; Thurow, 1992, 1996; Vatter \& Walker, 1996). This study examines the relationship between manufacturing employment and income inequality in the state of Alabama to test the hypothesis that manufacturing plays a key role in moderating inequality. The paper has four sections. The first outlines the changing nature of manufacturing in the U.S. and Alabama; the second discusses the linkage between the transformation of manufacturing and the growing income inequality in America over the past half century; the third describes our methodology; and the fourth presents the results from the Alabama case study.

The debate over whether the effects of inequality are primarily good or bad is beyond the scope of this paper. In brief, on the one hand, some analysts contend that high inequality represents a failure in development because a considerable number of people in a society are not benefitting from the operations of the economy and, more indirectly, because high inequality will probably inhibit human capital development (Bartels, 2008; Hacker and Pierson, 2010; Phillips, 1990; Sen, 1999; Stiglitz, Sen, and Fitoussi, 2010). Other scholars sharply refute this interpretation, arguing that inequality in social outcomes reflects inequality in human abilities that it is necessary to create the incentives which promote economic growth, and that trying to reduce inequality with welfare programs reduces the resources which can be devoted to productive activities (Block, 1990, 2000; Buchanan, 2013; Murray, 2005; Rothbard, 1979).

\section{The Transformation of U.S. Manufacturing}

The nature of the U.S. economy changed dramatically during the second half of the 20th century in two fundamental ways as America became an advanced technological society. First, manufacturing became much more capital intensive; and, second services assumed an ever increasing share of economic activity (Burea \& Kaboski, 2012). In particular, over the last fifty years, the U.S. has transitioned through three periods of manufacturing: "The Industrial Period" during 1945-1979, the "Deindustrialization of America" during 1980-2000, and "Re- 
industrialization of America" during 2000-present.

There is little controversy over the general dynamics of the competitive fortunes of the U.S. economy over the last century and a half. At the end of the Civil War, America was well behind Europe in economic development. What followed, though, was an era of surprising economic dynamism and rapid industrialization. By the beginning of the new century, the United States was challenging a faltering England as the strongest economic power in the world. Following the upheaval and devastation of two World Wars, American emerged as a true economic superpower whose economic predominance rivaled any that had existed before, in part because of the destruction of the rest of the industrialized world by World War II. In the late 1940s, for example, the U.S. accounted for $40 \%$ to $50 \%$ of global GDP. The economic recovery of the rest of the world during the quarter of a century of the postwar era, consequently, provided many opportunities for American exporters and multinational corporations (Gilpin, 1987; Gordon, 2016; Thurow, 1992).

Domestically, fears of reverting to the Great Depression reset America's economy to a demand-side economy (Garfinkle, 2006). The first three decades of the postwar era were characterized by relatively equal balance of blue-collar workers and white-collar workers that fulfilled industrial job demands and generated large amounts of revenues for the national treasury. Simultaneously, labor unions secured contracts and benefits for their members in the industrial sector and provided general prosperity among all levels of the workforce. The wealth established through the expanding manufacturing sector with its increasing wages stimulated a growing standard of living among the middle class, providing people with a single-home mortgage, stable jobs, and pensions, a dynamic true for people at all levels of education. The emergence of the affluent middle class, in turn, created a growing demand for more and newer consumer items (Bluestone \& Harrison, 1982; Lindsey, 2009; Vatter \& Walker, 1996). For example, during the period of 1950 to 1979 , Lindsey $(2009,37)$ concluded that "the American middle class experienced the greatest period of wealth creation and general prosperity in the history of the nation."

Deindustrialization is a process of systematic social and economic change caused by the removal or reduction of industrial capacity or activity in a country or region, especially the manufacturing sector (Lever, 1991). Until the 1980s, America was on the cutting edge of labor-intensive manufacturing employment. The 1980's, however, marked the beginning of the deindustrialization of America. This period experienced vanishing manufacturing employment, fluctuating productivity gains, lower consumer demands, increasing global competition, and an expanded service sector. By the beginning of the decade, sluggish growth and massive disinvestment in America's manufacturing sector became the common story and reality.

The underlying problem started to be recognized in the early 1980s, when the American middle class started being hit by the double whammy of global competition and labor-replacing technology (Bluestone and Harrison, 1982; Brady and Wallace, 2001; Danzinger and Gottschack, 1995; Lever, 1991; Russo and Linkon, 2009). As we just saw, globalization had generally helped the U.S. economically during the industrial era. However, during the 1960s American producers started to move the labor-intensive parts of their operations offshore to take advantage of decreasing transportation costs and the much lower wage levels that prevailed in developing countries (Alderson, 1997, 1999; Bluestone \& Harrison 1982; Brady \& Denniston, 2006; Brady \& Wallace, 2001; Clark \& Clark, 2016, 2020; Duesterberg \& Preeg, 2003; Green \& Sanchez, 2007; Kollmeyer, 2009; Kollmeyer \& Pichner, 2013; Reich, 2010; Ross \& Trachter, 1990; Wood, 1994, 1995). This serious loss of manufacturing jobs was exacerbated by the impact of automation in reducing factory employment (Editorial Board, 2017; Gillespie, 2017; Krause, 2017).

The current reindustrialization debate has introduced a new dynamic to global production efforts. Global corporations are returning to parts of America and particularly the South, but this looks quite different from the industrial period of America. The new face of manufacturing in America is high-tech robotics and machinery that replace the need for massive human labor. Although manufacturing is returning, it now accounts for only a small portion of the American workforce. For example, U.S. manufacturing employment fell from 19.6 million in 1979 to 11.8 million in 2011 (U.S. Department of Labor, 2011). The new reindustrialization period in America has overall less industrial employment, unstable productivity gains, higher unemployment, and more welfare dependency than the industrial period (Reich, 2010).

Alabama's manufacturing was traditionally concentrated in light industries, especially textiles and apparel, although steel was important as well. Deindustrialization saw the loss of most of the textile industry, as well as a considerable drop in steel production. For re-industrialization, Alabama has been quite successful in obtaining several world-leading automotive production plants. Over the past decade, global automotive firms, such as Mercedes Benz, Honda, Hyundai, Toyota, and Mazda located in Alabama. In addition, Alabama successfully recruited Airbus, General Electric Aviation, and Remington. The new large-scale industry in Alabama is predicted to have a major economic impact at the state and local level. On the other hand, Alabama's total employment in the manufacturing sector is fairly low compared to two decades earlier, despite the states' ability to recruit new innovative global corporations. Over the two decades that bracketed the turn of the century, the number of jobs in the state's manufacturing sector plummeted by $30 \%$ (Flynt, 2004; U.S. Department of Labor, 2012). 


\section{Industrial Transformation and Inequality}

For the last several centuries, economic development has been generally associated with industrialization or the transition from an economy based on agriculture and the work of artisans to one based on industry. In fact, through World War II, the few countries that industrialized generally grew rich, while the rest of the world remained mired in massive poverty. The nature of industrialization, of course, changed dramatically over the 19th and 20th centuries in terms of what industry was the most advanced or technological driver. The Industrial Revolution started with light industries, such as textiles and shoes, moved forward to such heavy industries as iron and steel, then moved into mass production with automobiles and other consumer durables, and finally peaked with the high tech industries and high quality industrial products. By the last third of the 20th century, post-industrial societies began to emerge in the developed world whose economies centered on services and the processing of information. In traditional economies, productivity increases are relatively small, but productivity (and consequently GDP) growth "take off" (Rostow, 1960) once industrialization starts. However, the advantages of the most advanced industrial nations will eventually be undercut as they move beyond high tech industry to a postindustrial society whose economy is dominated by the service sector where productivity gains come much more slowly than in manufacturing (Gilpin, 1987; Kuznets, 1976; Rostow, 1960; Thurow, 1992; Toffler and Toffler, 1980, 1995).

The deindustrialization era attracted extensive media coverage of plant closings across the U.S. Every newscast seemed to contain a story about a plant closing down, another thousand jobs disappearing from a community, or the frustration of blue-collar workers unable to find jobs providing enough income to support their families. In addition, related businesses like restaurants, clothing stores, industrial suppliers, barbershops and many other small businesses vanished from communities. Deindustrialization produced short-term and long-term socioeconomic effects within states and localities. In the short-term, deindustrialization increased the number of unemployed or displaced workers. In the long-term, declining manufacturing contributed greatly to a huge jump in communities littered with poverty, uneven income distribution, and crime (Alderson, 1997, 1999; Autor \& Dorn, 2013; Autor, Katz, and Kearney, 2008; Bluestone \& Harrison, 1982, 1988; Brady \& Wallace, 2001; Fallick, 1996; Friedman, 2011; Hacker and Pierson, 2010; Lever, 1991; Peck, 2011; Russo \& Linkon, 2009; Reich, 2010; Smith, 2012; Thurow, 1992, 1996; Wood, 1994).

Moreover, manufacturing employment decline generates a great deal of hardship for many workers and their communities. The social science literature suggests that high levels of poverty are highly correlated to community decline following plant closings, not to mention rising domestic violence, high school drop-out rates, and declining tax revenues. Communities need the wage and tax base provided by fixed capital investment in large scale manufacturing to support their households, schools, parks, clubs, hospitals, and civic and religious institutions. Cumulatively, these trends contributed to what Bluestone and Harrison (1988) call The Great U-turn, a reversal of the long-run pattern of decreasing income equality in the United States.

Deindustrialization, reindustrialization, and the economic changes associated with them may exacerbate inequality in a number of ways. De-industrialization destroyed many well-paying jobs; reindustrialization created far fewer jobs than had been destroyed and focused on skills that the old blue-collar workers did not possess; and the expanding service sector was marked by much greater inequality in skills and salaries than basic manufacturing had been (Alderson, 1999; Autor \& Dorn, 2013; Autor, Katz, and Kearney, 2008; Burea \& Kaboski, 2012; Chevan $\&$ Stokes, 2000). These structural changes explain much of the growing inequality in America, but another factor is important as well. This is the popularity of the business "low road" strategy of stressing cost minimization especially in salaries as the best method of increasing profits, which has clearly hurt the incomes of the working class (Clark \& Clark, 2011, 2020; Harrison, 1994).

\section{Data, Methodology, and Results}

This study utilizes a panel research design model to observe the influence on inequality exerted by manufacturing employment and a set of political, demographic, and socio-economic factors, using a county-level data set from the state of Alabama. This technique is appropriate for our analysis because it provides a means of quantitatively examining historical processes over a period of time. Because panel data create methodological problems for ordinary least squares (OLS) regression, this study utilizes the Random-effects (REM) model, which treats county specifics as a random component of the random-error (Beck \& Katz, 1995; Wilson \& Butler, 2007). Our analysis is based on U.S. Census Bureau (2012) data for Alabama's 67 counties for each year from 1970 through 2010. The dependent variable is the Gini coefficient of income inequality, which measures how much the distribution of income or consumption expenditure among individuals or households within an economy deviates from a perfectly equal distribution. The Gini ratio is a statistical measure of income equality ranging from 0 to 1 . A measure of 1 indicates perfect inequality; that is, one person has all the income and rest have none. A measure of 0 indicates perfect equality; that is, all people have equal shares of income. The Gini index measures the area between the Lorenz curve and a hypothetical line of absolute equality, expressed as a percentage of the maximum area under the line.

Alabama is plagued by comparatively high inequality in America. For example, Table 1 shows that it had the 
sixth highest Gini Coefficient among the U.S. states and the District of Columbia in 2008, trailing only California, Connecticut, Louisiana, New York, and Washington, D.C. In contrast, its level of unemployment is much less extreme. In 2008, for example its unemployment rate of 5.0\% put it almost exactly in the middle of the distribution of the states (see Table 2). This implies, then that there is something odd and out of the ordinary in the income distribution in Alabama.

Table 1: Alabama's Rank on Income Inequality (as Measured by the Gini Coefficient) Among the 50 States and District of Columbia, 2008

$\begin{array}{ll}\text { STATE } & \text { GINI } \\ \text { Washington, DC } & .5420 \\ \text { New York } & .5220 \\ \text { Louisiana } & .4990 \\ \text { Connecticut } & .4949 \\ \text { New York } & .4899 \\ \text { Florida } & .4852 \\ & \\ \text { Alabama } & .4847 \\ \text { Mississippi } & .4828 \\ \text { Georgia } & .4813 \\ \text { Kentucky } & .4813 \\ \text { New Jersey } & .4813 \\ \text { Illinois } & .4810 \\ \text { Texas } & .4800 \\ \text { Tennessee } & .4790 \\ \text { Massachusetts } & .4786 \\ \text { Rhode Island } & .4781 \\ \text { North Carolina } & .4780 \\ \text { New Mexico } & .4769 \\ \text { South Carolina } & .4735 \\ \text { Arkansas } & .4719 \\ \text { Arizona } & .4713 \\ \text { West Virginia } & .4711 \\ \text { Virginia } & .4705 \\ \text { Michigan } & .4695 \\ \text { Pennsylvania } & .4689 \\ \text { Ohio } & .4680 \\ & \end{array}$

$\begin{array}{ll}\text { STATE } & \text { GINI } \\ \text { Montana } & .4667 \\ \text { Missouri } & .4646 \\ \text { Oklahoma } & .4645 \\ \text { Washington } & .4591 \\ \text { Colorado } & .4586 \\ \text { Oregon } & .4583 \\ \text { Nevada } & .4577 \\ \text { Kansas } & .4550 \\ \text { Vermont } & .4539 \\ \text { North Dakota } & .4533 \\ \text { Indiana } & .4527 \\ \text { Delaware } & .4522 \\ \text { Maine } & .4519 \\ \text { Idaho } & .4503 \\ \text { Maryland } & .4499 \\ \text { Wisconsin } & .4498 \\ \text { Minnesota } & .4496 \\ \text { South Dakota } & .4495 \\ \text { Nebraska } & .4477 \\ \text { Iowa } & .4451 \\ \text { Hawaii } & .4420 \\ \text { Wyoming } & .4360 \\ \text { New Hampshire.4 }\end{array}$

New Hampshire.4304

Alaska $\quad .4081$

Utah $\quad .4063$

Source: U.S. Bureau of Labor Statistics. 2009. 
Table 2: Alabama's Rank on Unemployment Rate Among the 50 States and District of Columbia, 2008

$\begin{array}{lclc}\text { State } & \text { Unemployment Rate } & \text { State } & \text { Unemployment Rate } \\ \text { South Dakota } & 3.0 & \text { Washington } & 5.3 \\ \text { Wyoming } & 3.1 & \text { Massachusetts } & 5.3 \\ \text { North Dakota } & 3.2 & \text { Minnesota } & 5.4 \\ \text { Nebraska } & 3.3 & \text { Maine } & 5.4 \\ \text { Utah } & 3.4 & \text { Pennsylvania } & 5.4 \\ \text { New Hampshire } & 3.8 & \text { New York } & 5.4 \\ \text { Oklahoma } & 3.8 & \text { Arizona } & 5.5 \\ \text { Hawaii } & 3.9 & \text { New Jersey } & 5.5 \\ \text { Virginia } & 4.0 & \text { Connecticut } & 5.7 \\ \text { Iowa } & 4.1 & \text { Indiana } & 5.9 \\ \text { New Mexico } & 4.2 & \text { Missouri } & 6.1 \\ \text { West Virginia } & 4.3 & \text { Georgia } & 6.2 \\ \text { Maryland } & 4.4 & \text { Florida } & 6.2 \\ \text { Idaho } & 4.4 & \text { North Carolina } & 6.3 \\ \text { Kansas } & 4.4 & \text { Oregon } & 6.4 \\ \text { Montana } & 4.5 & \text { Tennessee } & 6.4 \\ \text { Louisiana } & 4.6 & \text { Kentucky } & 6.4 \\ \text { Wisconsin } & 4.7 & \text { Ohio } & 6.4 \\ \text { Vermont } & 4.8 & \text { Illinois } & 6.5 \\ \text { Colorado } & 4.8 & \text { Alaska } & 6.5 \\ \text { Delaware } & 4.9 & \text { Nevada } & 6.7 \\ \text { Texas } & 4.9 & \text { South Carolina } & 6.7 \\ \text { California } & 4.9 & \text { Mississippi } & 6.9 \\ & & \text { Washington, DC } & 7.0 \\ \text { Alabama } & 5.0 & \text { Rhode Island } & 7.8 \\ & & \text { Michigan } & 8.4 \\ \text { Arkansas } & 5.1 & & \end{array}$

Arkansas $\quad 5.1$

Source: U.S. Census Bureau. 2009.

Table 3 lists the five independent variables in the analysis along with their hypothesized relationship with inequality. Our key explanatory factor is the percentage of manufacturing employment which should have a negative association with inequality. Second, the percentage of blacks in a county should be positively correlated with inequality because of the general relationship between race and inequality, which should be especially strong here due to the historical barriers that African Americans have had to overcome in Alabama (Flynt, 2004). Third, income per capita should have a positive association with inequality because once development has reached a certain point, greater affluence results in lower inequality in the developed world (Kuznets, 1955). Fourth, more education should help a workforce get more skilled and higher paying jobs. Thus, inequality should be positively associated with the percentage of the population who did not finish high school. Finally, because of rural areas' lagging economic position in America and Alabama (Albrecht, Albrecht, \& Albrecht, 2000; Duncan, 1999; Flynt, 2004), rural counties in Alabama should have especially high levels of inequality.

Seven other explanatory variables were dropped from the analysis because they do not have a statistically significant independent influence on inequality: total population, $\%$ male population, retail sales per capita, interstate access, $\%$ federal civilian employment, $\%$ federal military employment, and \% state and local government employment.

At the highest level of development, greater development brings more inequality (Bartels,

2008; Hoeller, Joumaud, and Koske, 2014; OECD, 2012; Piketty, 2014; Stiglitz, 2013).

Table 3: Summary of Independent Variables

\begin{tabular}{|c|c|}
\hline PREDICTOR VARIBLE & $\begin{array}{c}\text { HYPOTHESIZED ASSOCIATION WITH INCOME } \\
\text { INEQUALITY }\end{array}$ \\
\hline \% Manufacturing Employment & Negative \\
\hline$\%$ Black Population & Positive \\
\hline Per Capita Income & Negative \\
\hline$\%$ No High School Diploma & Positive \\
\hline Rural County & Positive \\
\hline
\end{tabular}

The central concern of this analysis is the linkage between manufacturing employment and income inequality. This leads to the central research hypotheses:

H1 The percentage of manufacturing jobs should be inversely associated with the degree of income inequality in 
Alabama counties because manufacturing provides good jobs for the less skilled and educated.

We also developed hypotheses about how four control variables should affect inequality:

$\mathrm{H} 2$ Because of the long history of discrimination against African Americans in the state, the percentage of African Americans should be positively associated with inequality.

H3 Because of the normal pattern of development, inequality should be negatively related to income per capita.

H4 Because more education should produce more highly skilled workers, the percentage of residents without a high school diploma should be positively associated with inequality.

H5 Because of the lagging economies of rural areas, there should be a positive relationship between rurality and inequality.

The regression results in Table 4 provide a definitive evaluation of these hypotheses. It should be stressed that the effects attributed to manufacturing employment (or any other explanatory variable) represent its individual influence after the effects of the other four independent variables have been statistically controlled. Also, the numerical scale of the Gini Coefficient, the dependent variable, is not particularly meaningful beyond the fact the higher values denote greater inequality. Consequently, the absolute values of $b$ are almost impossible to interpret. Hence, our analysis focuses on the statistical significance of a relationship. Also, because the range of the Gini Coefficient is a small decimal (e,g., see Table 1), the b's, which represent the change in the Gini index produced by a one-unit increase in the independent variable are small as well.

Table 4: Regression Estimates for the Independent Variables Explaining the Level of Income Inequality (as measured by the Gini Coefficient) in Alabama Counties, 1970-2010 (all coefficients are unstandardized b's)

\begin{tabular}{|l|l|}
\multicolumn{1}{|c|}{$\begin{array}{c}\text { INDEPENDENT } \\
\text { VARIABLE }\end{array}$} & \multicolumn{1}{c|}{$\mathrm{b}$} \\
\hline$\%$ Manufacturing Employment & $-.00125^{* * *}$ \\
\hline \% Black Population & $.00079^{* * *}$ \\
\hline Per Capita Income & $-.0000035^{* * *}$ \\
\hline \% No High School Diploma & $.1467 * * *$ \\
\hline Rural County & $.0162^{* * *}$ \\
\hline $\mathrm{R}^{2}$ & \\
\hline
\end{tabular}

$* * * \mathrm{p}<.001$

Source: U.S. Census Bureau. 2012

The percentage of manufacturing is strongly related to income inequality at the .001 level of significance in the predicted negative in direction. Clearly, therefore, "manufacturing matters" (Cohen \& Zysman, 1987; Green \& Sanchez, 2007; Uchitelle, 2017) in moderating extreme inequality. Moreover, the four control variables also have strong predicted influences on inequality that are statistically significant at the .001 level. In particular, the proportion of African Americans, the proportion of residents who did possess a high school diploma, and the rurality of a county are all associated with higher levels of inequality, while per capita income has a negative association. Overall, the five independent variables exercise a very strong impact on the level of inequality in Alabama, as indicated by the Multiple R2 of .77.

\section{Implications}

Our case study of Alabama counties certainly demonstrates that "manufacturing matters" for income inequality at the local level in that state, as counties with higher levels of manufacturing have less inequality even after other major influences are statistically controlled. Thus, traditional manufacturing helps to mitigate the adverse effects of deindustrialization and re-industrialization in the United States. Other key findings are that more educated communities have less inequality, that rural areas have especially high inequality, that counties with a high proportion of African Americans face disproportionately high inequality, and that the poorest counties have the highest level of inequality. Furthermore, this is not just an American problem. Rather, most advanced industrial societies suffer from the same interlinked trends of rising inequality and declining manufacturing employment (Alderson, 1997, 1999; Brady \& Denniston, 2006; Kollmeyer, 2009; Kollmeyer \& Pichler 2013; Wood, 1994).

These findings strongly suggest that much more attention should be paid to the conditions facing the working class in the increasingly post-industrial economies of the developed world. In the United States, perhaps strangely, neither of the two major parties have developed economic policies that would appeal to the working class. This changed dramatically in the 2016 presidential election when Republican Donald Trump promised to "Make America Great Again" by creating good working-class jobs by a combination of tax cuts for the business and wealthy, deregulation, trade protection, a crackdown on immigration, and jawboning corporations to keep jobs in and/or bring them back to America. However, there are several reasons to question the viability of this program. First, the Trump administration has ignored other important causes of the squeeze on the working class, such as automation and business's "low road" strategy of cost minimization. Second, several of his policy initiatives, such as implementing tariffs and cracking down on immigration, have components that might conflict with one another. Third, some of these policies are also controversial among important constituencies within the Republican Party 
(Clark and Clark, 2020).

During the late 20th and early 21 st centuries, the United States commenced a transition from an industrial to an information-age economy (Clark and Clark, 2016; Toffler and Toffler, 1980, 1995). In general, there appear to be two probably contradictory strategies for making the best of this unsettling transformation. One would be to turn back the transformation of manufacturing in order to reverse some of its unwanted consequences. Given the questions that have arisen about President Trump's program to do just that, however, the viability of such an effort seems problematic. The other strategy would be to adjust to the ongoing economic change so that more people can benefit from it. Here, our finding that more educated counties have lower income inequality implies that more resources should be devoted to preparing Americans for the emerging 21st century economy. However, this does little, if anything, to help the victims of deindustrialization and re-industrialization. Where we can perhaps look for inspiration for a more effective strategy is to the 1980s efforts of Western Europe (Katzenstein, 1985) and Japan (Calder, 1988) to provide "compensation" to those who had been left behind by economic change.

The reality of manufacturing shifts over the past forty years is obvious, but the path forward is questionable. Policy-makers are faced with creating economic resolutions for the waning middle class through the growth of high-tech manufacturing production yet struggle with developing and retaining an educated workforce that keeps up with the pace of technology developments and demands in the global economy. Modern re-industrialization has the opportunity to raise the local GDP and generate new tax revenue, but the growth of a larger middle class remains uncertain. Reindustrialization with advanced manufacturing will restore some manufacturing production in the US, but this economic strategy may not be the path to prosperity for an underdeveloped workforce.

Many states struggle to respond to the new education and training demands of modern manufacturing. Thus, new education reform, industrial apprenticeships, and tax reform not only have the potential to improve Alabama's local economy and the middle-class standard of living, but also provide positive reinforcement for the economic and political objectives that support a thriving middle-class economy. Education reform is a vital factor in a prosperous middle class, but it is questionable which type of reform is most beneficial to the local economy. Most Governors over the past two decades have listed education reform as a top priority in their policy agenda, which shows that states are aware of the educational gaps and workforce shortages.

Does the future of the global economy rest in safe arms with the new reindustrialization strategy and education reform? States and local governments must ascertain what mix of higher education reform, K-12 reform, career readiness, and high-tech training is the best equation for the growing workforce deficit and waning middle class. In addition, education reform must consider high-tech automation, robotics, and artificial intelligence as a curriculum component in education reform. This policy area must be constructed in ways that not only broaden the middle class but help the victims of deindustrialization and reindustrialization.

\section{Future Research}

This case study of Alabama strongly suggests that manufacturing matters in the early 21 st century. The growing trend in deindustrialization, consequently, represents a clear threat to the prosperity of a significant segment of citizens. What this does, hence, is to making a growing emphasis on workforce development vital for ensuring the wellbeing of the victims of deindustrialization. Middle class prosperity can be achieved through workforce and economic policy efforts that addresses the challenges incurred by deindustrialization and globalization. Specifically, governments should invest in developing the future workforce and preparing citizens to respond to the increasing demand of high-tech automation and automation in all industries. This policy goal can be achieved with the implementation and research of American manufacturing re-investment (Bluestone and Harrison, 1982; Brady and Wallace, 2001; Lever, 1991; Russo and Linkon, 2009), work-based learning policy and Career Pathways educational programs (Solberg, Phelps, Haakenson, Durham, \& Timmons, 2012). This research can provide valuable insight to several of the pressing workforce and economic development concerns globally. While the service and knowledge-based industries are not classified as manufacturing, its correlation and support to the manufacturing industry and the overall economy is necessary (Sala-I-Martin et al., 2014).

\section{References}

Albrecht, D. E., Albrecht, C. M. \& Albrecht, S. L. (2000). Poverty in nonmetropolitan America: Impacts of industrial, employment, and family structure variables. Rural Sociology, 61, 87- 103.

Alderson, A. (1997). Globalization and deindustrialization: Direct investment and the decline of manufacturing employment in 17 OECD nations. Journal of World Systems Research, 3, 1-34.

Alderson, A. S. (1999). Explaining deindustrialization: Globalization, failure, or success?" American Sociological Review, 64, 701-721.

Autor, D., \& Dorn. D. (2013). The growth of low-skill service jobs and the politicization of the U.S. labor market. American Economic Review, 103, 1553-1597.

Autor, D., Katz, L.F., \& Kearney, M.S. (2008). Trends in U.S. wage inequality: Revising the revisionists. Review of Economics and Statistics, 90, 300-323. 
Bartels, L. M. (2008). Unequal democracy: The political economy of the new gilded age. Princeton: Princeton University Press.

Beck, N., \& Katz, J. N. (1995). What to do (and not to do) with time-series cross-section data. American Political Science Review, 89, 634-647.

Block, W. E. (1990). Reconciling efficiency, freedom, and equality. In Pendse, S. (Ed.), Options in Economic Design. Westport, CT: Greenwood.

Block, W. E. (2000). Is inequality harmful for growth? Humanomics, 16(2), 52-58.

Bluestone, B., \& Harrison, B. (1982). The deindustrialization of America: Plant closings, community abandonment, and the dismantling of basic industry. New York: Basic Books.

Bluestone, B., \& Harrison, B. (1988). The great U-turn: Corporate restructuring and the polarization of America. New York: Basic Books.

Brady, D., \& Denniston, R. (2006). Economic globalization, industrialization and deindustrialization in affluent democracies. Social Forces, 85: 297-329.

Brady, D., \&. Wallace, M. (2001). Deindustrialization and poverty: Manufacturing decline and AFDC recipientcy in Lake County, Indiana 1964-93. Sociological Forum, 16, 321-358.

Buchanan, P. J. (2013). Inequality - Crisis or scam. Patrick J. Buchanan-Official Website, December 31, www.buchanan.org

Burea, F. J., \& Kaboski, J. P. (2012). “The rise of the service economy.” American Economic Review, 102, 25402569.

Calder, K. (1988). Crisis and compensation: Public policy and political stability in Japan, 1949- 1986. Princeton: Princeton University Press.

Chevan, A., \& Stokes, R. (2000). "Growth in family income inequality, 1970-1990: Industrial restructuring and demographic change. Demography, 37, 365-380.

Clark, C., \& Clark, E. A. (2011). America's response to globalization and financial crisis: The 'high road' and 'low road' alternatives. International Journal of Contemporary Sociology, 48, 305-331.

Clark, C., \& Clark, E. A. (2016). The swirl of globalization through the U.S. political economy. In Gonzalez, B. (Ed.), Globalization: Economic, political and social issues. New York: Nova Science.

Clark, C., \& Clark, E. A. (2020). Preserving Basic U.S. Industries: The Implications of Trumponomics. New York: Nova Science.

Cohen, S. S., and Zysman, J. (1987). Manufacturing matters: The myth of a post-industrial economy. New York: Basic Books.

Dadush, U., Dervis, K., Milsom, S. P., \& Stancil, B. (2012). Inequality in America. Washington, DC: Brooking Institution Press.

Danziger, S. H., \& Gottschalk, P. (1995). America unequal. Cambridge: Harvard University Press.

Duesterberg, T. J., \& Preeg, E. H. (Eds.). (2003). U.S. manufacturing: The engine for growth in a global economy. Westport, CT: Praeger Publishers.

Duncan, C. M. (1999). Worlds apart: Why poverty persists in rural America. New Haven: Yale University Press.

Editorial Board. (2017). No, robots aren't killing the American dream. New York Times, February 20, www.nytimes.com.

Fallick, B.C. (1996). A review of the recent empirical literature on displaced workers. Industrial and Labor Relations Review, 50, 5-16.

Flynt, J.W. (2004). Alabama in the twentieth century. Tuscaloosa: University of Alabama Press.

Friedman, T. L. (2011). The uncertainty tax. New York Times, June 11, www.nytimes.com.

Garfinkle, N. (2006). The American dream vs. the gospel of wealth: The fight for a productive middle-class economy. New Haven: Yale University Press.

Gillespie, P. (2017). Rise of the machines: Fear robots, not China or Mexico. CNN, January 30, www.cnn.com.

Gilpin, R. (1987). The political economy of international relations. Princeton: Princeton University Press.

Gordon, R. J. (2016). The rise and fall of American growth: The U.S. standard of living since the Civil War. Princeton: Princeton University Press.

Green, G. P., \&. Sanchez, L. (2007). “Does manufacturing still matter?” Population Resolution Policy Review, 26, 529-551.

Hacker, J .S., \& Pierson, P. (2010). Winner take all politics: How Washington has made the rich richer and turned its back on the middle class. New York: Simon \& Schuster.

Harrison, B. (1994). Lean and mean: The landscape of corporate power in the age of flexibility. New York: Basic Books.

Hoeller, P., Jounard, I \& Koske, I. (Eds.). (2014). Income inequality in OECD countries. Singapore: World Scientific Press.

Katzenstein, P. (1985). Small states in world markets: Industrial policy in Europe. Ithaca: Cornell University Press. Kollmeyer, C. (2009). Explaining deindustrialization: How affluence, productivity growth, and globalization 
diminish manufacturing employment. American Journal of Sociology, 114 , 1644-1674.

Kollmeyer, C., \& Pichler, F. (2013). Is deindustrialization causing high unemployment in affluent countries? Evidence from 16 OECD countries, 1970-2003. Social Forces, 91, 785-812.

Krause, C. (2017). Texas oil fields rebound from price lull, but jobs are left behind. New York Times, February 19, www.nytimes.com.

Kuznets, S. (1955). Economic growth and income inequality. American Economic Review, 45, 1- 28.

Kuznets, S. (1976). Modern economic growth: Rate, structure, spread. New Haven: Yale University Press.

Lever, W. F. (1991). Deindustrialisation and the reality of the post-industrial city. Urban Studies, 28, 983-999.

Lindsey, D. (2009). Child poverty and inequality: Securing a better future for America's children. New York: Oxford University Press.

Murray, C. (2005). The inequality taboo. Commentary, September, www.aei.org

Organization for Economic Co-operation and Development (OECD). (2012). Divided we stand: Why inequality keeps rising. Paris: OECD.

Peck, D. (2011). Pinched: How the Great Recession has narrowed our futures and what we can do about it. New York: Crown.

Phillips, K. (1990). The politics of rich and poor: Wealth and the American electorate in the Reagan aftermath. New York: Random House.

Piketty, T. (2014). Capital in the Twenty-First Century. Cambridge: Cambridge University Press.

Reich, R. B. (2010). After-shock: The next economy and America's future. New York: Alfred A. Knopf.

Ross, R. J., \& Trachte, K. C. (1990). Global capitalism: The new leviathan. New York: State University of New York Press.

Rostow, W. W. (1960). The stages of economic growth: A non-communist manifesto. Cambridge: Cambridge University Press.

Rothbard, M. (1979). Freedom, inequality, primitivism, and the division of labor. In Templeton, K.S., Jr. (Ed), The Politicization of Society. Indianapolis: Liberty Press.

Russo, J., \& Linkon S. L. (2009). The social cost of deindustrialization. Youngstown, OH: Youngstown State University, Center for Working-Class Studies.

Sala-I-Martin, X., Bilbao-Osorio, B., Battista, L. D., Drzeniek, M., Galvan, H. C., \& Geiger, T. (2014). The global competitiveness index 2-14-15. Accelerating a robust recover to create productive jobs and support inclusive growth. In World Economic Forum (Ed.), The global competitiveness report 2013-2014. Geneva: World Economic Forum. RetrievedJanuary6,2014, from www3.weforum.org/docs/WEF_GlobalCompetitivenessReport_2014-15.pdf.

Sen, A. (1999). Development as freedom. New York: Anchor Books.

Smith, H. (2012). Who stole the American dream? New York: Random House.

Solberg, V. S., Phelps, L. A., Haakenson, K. A., Durham, J. F., \& Timmons, J. (2012). The nature and use of individualized learning plans as a career intervention strategy. Journal of Career Development, 39, 500-514.

Stiglitz, J. E. (2013). The price of inequality: How today’s divided society endangers our future. New York: W.W. Norton.

Stiglitz, J., Sen, A., \& Fitoussi, J. P. 2010. Mismeasuring our lives: Why GDP doesn't add up. New York: The New Press.

Thurow, L. (1992). Head to head: The coming battle among Japan, Europe, and America. New York: Warner.

Thurow, L. C. (1996). The future of capitalism: How today's economic forces shape tomorrow's world. New York: Morrow.

Toffler, A., \& Toffler, H. (1980). The third wave. New York: Morrow.

Toffler, A., \& Toffler, H. (1995). Creating a new civilization: The politics of the third wave. Atlanta: Turner.

Uchitelle, L. (2017). Making it: Why manufacturing still matters. New York: New Press.

U.S. Bureau of Labor Statistics (2009). Regional and state unemployment: 2008 annual average. Washington, DC: U.S. Bureau of Labor Statistics.

U.S. Census Bureau. (2009). American community survey. Washington DC: U.S. Census Bureau.

U.S. Census Bureau. (2012). Data on Alabama counties. Washington DC: U.S. Census Bureau.

U.S. Department of Labor. (2011). Statistics. Washington, DC: U.S. Department of Labor, Bureau of Statistics.

U.S. Department of Labor. (2012). Statistics. Washington, DC: U.S. Department of Labor, Bureau of Statistics.

Vatter, H. G., \& Walker, J. F. (Eds.). (1996). History of the U.S. Economy since World War II. Armonk, NY: M.E. Sharpe.

Wilson, S. E., \& Butler, D. M. (2007). A lot more to do: The sensitivity of time-series cross- section analyses to simple alternative specifications. Political Analysis, 15, 101-123.

Wood, A. (1994). North-south trade, employment and inequality: Changing fortunes in a skill- driven world. Oxford: Clarendon Press.

Wood, A. (1995). How trade hurt unskilled workers. Journal of Economics Perspectives, 3(3), 57-80. 


\section{First Author}

Dr. Nicholas Bolden is an Assistant Professor of Public Administration and Policy at Columbus State University. His major teaching and research interest focus on state and local policy and public management, specifically in the areas of economic development, workforce development, and state and local government finance. Dr. Bolden has taught extensively in the field of public administration and provides training and policy consultant services to state and local agencies. Recently, Dr. Bolden served as a Work-Based Learning policy consultant to the Alabama Department of Commerce and The Office of the Governor, Kay Ivey. His recent peer-reviewed publications appeared in the Journal of Regional and Policy Analysis and The Journal of Economics and Sustainable Development. Nicholas Bolden received a Master of Public Administration from Troy University with a specialization in Adult Education and Training, and a Ph.D. in Public Administration and Policy from Auburn University.

\section{Second Author}

Dr. Cal Clark is an Emeritus Professor of Political Science and MPA Director at Auburn University who received his $\mathrm{PhD}$ from the University of Illinois. His research focuses upon economic development policy, and his most recent book is the co-authored Preserving Basic U.S. Industries: The Implications of Trumponomics.

\section{Third Author}

Dr. James Korku Agbodzakey is an Associate Professor of Public Leadership, the Director of the Urban SERCH Institute at UNT Dallas, and the current President of Conference of Minority Public Administrators (COMPA 2020-2021). His principal research focuses on HIV/AIDS care and treatment/health policy, nonprofit governance, public procurement and on building resilient communities. He has extensive work experience in public, private, civic/nonprofit sectors in Africa, Caribbean, and the United States of America. His recent publications appeared in journals such as International Review of Public Administration, International Journal of Procurement Management, Public Organization Review, and Journal of Economics and Sustainable Development. 